\title{
Bony Fish Bycatch in the Southern Brazil Pink Shrimp (Farfantepenaeus brasiliensis and $F$. paulensis) Fishery
}

\author{
Marcelo Vianna ${ }^{1 *}$ and Tabajara Almeida ${ }^{2}$ \\ ${ }^{I}$ Departamento de Biologia Marinha; IB; CCS; Universidade Federal do Rio de Janeiro; Ilha do Fundão; \\ 21949-900; Rio de Janeiro - RJ - Brasil. ${ }^{2}$ Departamento de Estatística; Fundação Universidade Federal do Rio \\ Grande; Rio Grande - RS - Brasil
}

\begin{abstract}
Trawling for pink shrimp (Farfantepenaeus brasiliensis and $\mathrm{F}$. paulensis) catches also large quantities of fish, mostly bony fish, which are discarded, as they have no commercial value. Their composition and abundance were studied in an area that corresponded to the southeastern coastline of Brazil. Ninety one species were registered. Incidental fishing affected mainly small individuals and occured throughout the year. The year round rate of bony fish to shrimp catches was 10,5:1,0. Three assemblages of bony fishes could be identified, influenced by the seasonal variation of the water masses, the predominant group being associated with the Coastal Water, another with the penetration of colder waters onto the platform (SACW) and a third group of a more homogenous distribution. The most critical period identified for the bycatch capture was the beginning of the winter, which was due to the overlapping of fish assemblages and the peak of fishing recruitment.
\end{abstract}

Key words: Bycatch, bony fishes, demersal fish, shrimp fisheries

\section{INTRODUCTION}

The on-board discarding of part of the incidental capture is currently one of the biggest, if not the major, problem faced by the world fishing industry. In order to manage fishery effectively, there must be knowledge of the discard resulting from this activity, especially regarding the shrimp fisheries, which is responsible for the largest discard rate (Hall, 1999). Alverson et al. (1994) estimated that it accounted for six times the weight of the shrimp landed and what was even greater in tropical regions, due to the high price of shrimp destined mainly to the external market (Clucas, 1998). According to López (1999), the Americas' shrimp fishery produced $93 \%$ of the total bycatch, with a discard rate of $80 \%$.

Brazilian's Southeast and South coastal fleets of shrimp trawlers are the most numerous in the country. This type of fishing captures a large number of organisms along with the shrimp, due to the large local biodiversity and low selectivity of nets. Some of the specimens captured are landed and sold separately grouped by similarity, or commercialized altogether in category mixture. However, most of the bycatch is discarded on board as it does not have commercial value and is returned to the sea dead or with small chance of survival. Vazzoler (1962) was the first to attempt to deal with this problem in Brazil, but only in the 80 's, when marine resources already gave signs of

\footnotetext{
*Author for correspondence
} 
exhaustion, the research was resumed (e.g. Coelho et al., 1986).

In recent years, several studies have been carried out to quantify the worldwide bycatch; however, there is still lack of information regarding the composition, size and seasonal variation of this kind of capture. Reviewing the subject, Alverson et al. (1994) reported that available data were incomplete, but observed that for the North Atlantic various studies on the bycatch were published, whereas for the South Atlantic there was still little information available. In Brazil studies of discarding are rare. In spite of the volume of bycatch from the shrimp fishery, the species of which it is composed are seldom studied (Morais et al., 1995). This is typical of South America (Haimovici and Mendonça, 1996) and also to the whole Americas (López, 1999).

From an economic point of view, fish constitutes the most abundant and important part of the bycatch. Studies published on the fish captured with the shrimp fishing in southeastern Brazilian basically rely on outdated information and related to the fleet that catches the Sea-bob shrimp (Xiphopenaeus kroyeri), at depths between 4-20 m (Coelho et al., 1986). The fishes caught in southern Brazil were analyzed by Ruffino and Castello (1992/93), in their studies on the fisheries of the Argentinian stiletto shrimp (Artemesia longinaris), by Haimovici and Mendonça (1996) regarding the A. longinaris and the Argentinian red shrimp (Pleoticus muelleri). Damasceno and Evangelista (Isaac, 1999) working on the Southern brown shrimp (Farfantepenaeus subtilis) conducted this study for the fishes caught in norther Brazil. As the information available on Brazil's shrimp bycatch fishing is limited in great part to the $20 \mathrm{~m}$ isobath, this present study concentrates on the material captured mostly at $30 \mathrm{~m}$ depth. For Pink shrimp fishing ( $F$. brasiliensis and $F$. paulensis) on the southeastern coast, only Kotas (1998) has published information on this fishery bycatch, but basically used data on profitable fishes only.

The aim of this paper was to analyze the bony fish species composition and the proportion of the bycatch capture of Pink shrimp fishing, on the southeastern Brazilian coast, identifying tendencies in the distribution of the occurrence of those species, suggesting measures for the reduction of this capture.

\section{General characteristics of the area}

The study area was situated on Brazil's Southeastern coast between, the north of São Paulo and the south of Rio de Janeiro. Although the sector studied was relatively limited, it represented the fishing in this region well, because $59 \%$ of the fleet allowed to exploit Pink shrimp fisheries on the southeast and south Brazilian coastline was been concentrated in the São Paulo state (CEPSUL, 1994).

According to Furtado and Mahiques (1990), the area within the region studied is composed by an inclination that descends to the $60 \mathrm{~m}$, followed by an internal platform and a slope between the $80 \mathrm{~m}$ isobath that stretches downwards to an external platform. During summer the South Atlantic Central Water (SACW) penetrates the Continental Platform as far as the coastal region, compressing the Coastal Water mass, which is warmer. In winter, the SACW withdraws in direction of the Continental Platform (Castro-Filho et al., 1987). Therefore, the region presents two domains, an internal one that extends from the coast to the 40$50 \mathrm{~m}$ isobaths, and an external one stretching out to the edge of the platform. The area studied in this work corresponded to the internal domain's boundary in the zone of mixed water masses.

The zoogeography region is situated in the North Argentine Marine Province that covers the area between Rio de Janeiro and the Valdez Peninsula, being characterized by a fish assemblage consisting of species with distribution restricted to the area. It also represents the austral borders of the tropical species and also the septentrional temperate waters species (Vazzoler et al., 1999).

\section{MATERIALS AND METHODS}

\section{Sampling and data colletion:}

Monthly samples were obtained from the commercial double rig trawl (17 meters) pink shrimp ( $F$. paulensis and $F$. brasiliensis) fishery from September 1995 to August 1996, except in the closed season, in March and April 1996, when the samples were obtained from smaller trawlers fishing for Xiphopenaeus kroyeri. Each month all bony fishes in one haul of the nets was landed and sorted to species. The net had a $25 \mathrm{~mm}$ mesh between opposing knots at the codend and a length of $18 \mathrm{~m}$ on the upper side and $20 \mathrm{~m}$ at the bottom. The trawls were carried out at $2.5 \mathrm{kn}$ and were nocturnal (Table. 1). Simultaneously from 
September 1994 to September 1998, observations of local shrimp fleet catches were made almost daily, registering the species landing and the manners of commercialization.

\section{Data analysis}

Total weight and number of the sizes of the fishes of each species were recorded for each monthly sample and CPUE in weight (CPUEw - g/h) and numbers (CPUEn - ind/h) were calculated. Biological diversity of fish assemblage was analyzed by season, using the non dimensional index of Richness (Margalef), Diversity (Shannon) and Equitability (Pielou), as described in Ludwig and Reynolds (1988), based on capture in weight as well as on relative abundance in number of individuals.

For species of economic importance and with more than $90 \%$ of frequency of occurrence during sampling, the length structure was analyzed from the tabulation of the number of individuals per total length class. On board utilization and means of commercialization of the species captured were evaluated from interviews with the vessel's master fishermen and periodical observations of landings catches.

Table 1 - Collection fishery data used for study, where the given coordinates for each station refer to an average point, the haul area, corresponding to trawl.

\begin{tabular}{|c|c|c|c|c|}
\hline Coordinates & Month & $\begin{array}{c}\text { Average } \\
\text { depth (m) }\end{array}$ & $\begin{array}{l}\text { Beginning of } \\
\text { trawl time }\end{array}$ & $\begin{array}{c}\text { Duration of } \\
\text { trawl (h) }\end{array}$ \\
\hline $23^{\circ} 48^{\prime} \mathrm{S} / 45^{\circ} 01^{\prime} \mathrm{W}$ & $\mathrm{Jul} / 95$ & 45 & 02:00 & 5.00 \\
\hline $23^{\circ} 40^{\prime} \mathrm{S} / 44^{\circ} 53^{\prime} \mathrm{W}$ & Aug/95 & 43 & 03:00 & 4.00 \\
\hline $23^{\circ} 41^{\prime} \mathrm{S} / 45^{\circ} 02^{\prime} \mathrm{W}$ & Sep/95 & 41 & 01:00 & 5.00 \\
\hline $23^{\circ} 36^{\prime} \mathrm{S} / 45^{\circ} 01^{\prime} \mathrm{W}$ & Oct/95 & 37 & 02:00 & 4.00 \\
\hline $23^{\circ} 21^{\prime} \mathrm{S} / 44^{\circ} 32^{\prime} \mathrm{W}$ & Nov/95 & 35 & $03: 30$ & 4.00 \\
\hline $23^{\circ} 38^{\prime} \mathrm{S} / 45^{\circ} 04^{\prime} \mathrm{W}$ & Dec/95 & 35 & $01: 30$ & 4.00 \\
\hline $23^{\circ} 28^{\prime} \mathrm{S} / 44^{\circ} 55^{\prime} \mathrm{W}$ & Jan/96 & 31 & $03: 30$ & 3.50 \\
\hline $23^{\circ} 27^{\prime} \mathrm{S} / 44^{\circ} 45^{\prime} \mathrm{W}$ & Feb/96 & 37 & $02: 30$ & 4.00 \\
\hline $23^{\circ} 25^{\prime} \mathrm{S} / 44^{\circ} 52^{\prime} \mathrm{W}$ & Mar/96 & 22 & $11: 00$ & 3.00 \\
\hline $23^{\circ} 26^{\prime} \mathrm{S} / 44^{\circ} 52^{\prime} \mathrm{W}$ & Apr/96 & 24 & $10: 00$ & 2.00 \\
\hline $23^{\circ} 26^{\prime} \mathrm{S} / 44^{\circ} 35^{\prime} \mathrm{W}$ & May/96 & 51 & 02:00 & 4.00 \\
\hline $23^{\circ} 42^{\prime} \mathrm{S} / 45^{\circ} 06^{\prime} \mathrm{W}$ & Jun/96 & 35 & $01: 30$ & 4.00 \\
\hline $23^{\circ} 38^{\prime} \mathrm{S} / 45^{\circ} 01^{\prime} \mathrm{W}$ & Jul/96 & 42 & 01:00 & 6.00 \\
\hline $23^{\circ} 25^{\prime} \mathrm{S} / 44^{\circ} 40^{\prime} \mathrm{W}$ & Aug/96 & 41 & $02: 30$ & 4.00 \\
\hline
\end{tabular}

To identify the occurrence of possible tendencies in the distribution of species, some of the species captured were eliminated from the analysis, as they would represent information background noise, since they would not normally appear among the others which were characteristic of the fishing study. Cluster Analysis was employed, with an option for the unweighted pair-group average (UPGMA) amalgamation technique (Sneath and Sokal, 1973), by which the distance between two groups is calculated as the average distance between all pairs of objects in two different groups. For the measurement of distance, Euclidean distance was employed, considered a very efficient measure of similarity and often used (Ludwig and Reynolds, 1988).

Once the main species had been selected, Correspondence Analysis was employed as an exploratory/descriptive technique of association between species. To avoid the excessive influence of one measured variable in the analysis, it was decided to work with the product of them (CPUEn $\mathrm{x}$ CPUEw). The coordinates were standardized with the column and row profile, suitable for the interpretation of distance between rows (species) as well as columns (sampling months) in the data matrix.

\section{RESULTS}

\section{Composition and relative abundance}

During the collection 17,141 specimens of 91 species were captured, corresponding to 38 families (Table 2). Sciaenidae and Bothidae were the families that presented the largest number of species (Fig. 1), representing together $26 \%$ of the overall total. Sciaenidae, Batrachoididae and Triglidae, represented together $62 \%$ of the total capture in numbers of individuals and $63 \%$ of the 
capture in weight (Table 3), due mainly to the abundance of $P$. porosissimus, $P$. punctatus, $C$. gracilicirhus, $C$. jamaicensis and $P a$. brasiliensis. It was worthy to note that the larger part of the capture consisted of just a few species. Only $23.1 \%$ had a frequency of occurrence equal to or greater than $75 \%$ and $47.3 \%$ were captured in $25 \%$ or less of the effective sampling.

CPUEn, CPUEw and biological diversity index showed seasonal variation in the composition and abundance of species registered (Table 3). March and April closed season samples had higher CPUE and slightly higher biological diversity. They were not staightfordward comparable to the other months. Considering the total number of species, the peak of captures in May-June was maximum both in number and in weight. In biological diversity, although the values were very close, an increase was noticed for this period, mainly as regards the number of individuals captured.

\section{Estimates of rejection and biological diversity}

The proportion of the relationship between Pink shrimp and bycatch by average weight per hour of trawling (Table 4), showed a large capture of bony fishes, with a mean of $10.5 \mathrm{~kg}$ of fish per kilogram of shrimps. However, these proportions oscillated over the two months of the study, showing a seasonal variation in abundance of species and highlighting May-June as presenting the highest value for this relationship.

Table 2 - Number of individuals (N), capture in weight (g), frequency of occurrence (\% FO) and range of total size $(\mathrm{Lt})$, for species of fish recorded during the study. Where: destination -

- pelagic, soft bottom demersal and hard bottom demersal.

\begin{tabular}{|c|c|c|c|c|c|c|}
\hline SPECIES & local name & $\mathbf{N}$ & weight (g) & Lt. $(\mathbf{c m})$ & \% FO destination & labitat \\
\hline ANTENNARIIDAE & & 6 & 95.2 & & & \\
\hline Antennarius striatus & - & 6 & 95.2 & $3.5-11.5$ & 41.7 & \\
\hline BALISTIDAE & & 63 & 9513 & & & \\
\hline Balistes capriscus & Peixe-porco & 63 & 9513.1 & $14.0-36.0$ & 41.7 & 䀁 \\
\hline BATRACHOIDIDAE & & 2755 & 93183 & & & \\
\hline Porichthys porosissimus & Mamangá-liso & 2741 & 92144.7 & $7.5-29.0$ & 100.0 & \\
\hline Thalassophryne montevidensis & Mamangá-liso & 14 & 1038.1 & $11.5-18.5$ & 58.3 & \\
\hline BOTHIDAE & & 1206 & 23787.7 & & & \\
\hline Bothus ocellatus & Linguado & 3 & 67.8 & $12.6-13.5$ & 8.3 & \\
\hline Bothus robinsi & Linguado & 6 & 146.4 & $13.5-16.5$ & 8.3 & \\
\hline Cyclopsetta chittendeni & Linguado & 4 & 384.4 & $13.0-17.5$ & 16.7 & \\
\hline Citharichthys spilopterus & Linguado & 1 & 84.6 & 13.5 & 8.3 & \\
\hline Etropus crossotus & Linguado & 508 & 5830 & $8.0-15.0$ & 58.3 & \\
\hline Etropus longimanus & Linguado & 449 & 4952.7 & $6.5-13$ & 83.3 & \\
\hline Paralichthys patagonicus & Linguado & 213 & 9801.3 & $10.0-41.0$ & 83.3 & \\
\hline Paralichthys triocellatus & Linguado & 3 & 236.8 & $15.5-16.0$ & 8.3 & \\
\hline Syacium micrurum & Linguado & 2 & 29.5 & $10.7-13.8$ & 8.3 & \\
\hline Syacium papillosum & Linguado & 12 & 1956.9 & $10.7-24.0$ & 58.3 & \\
\hline Verecundum rasile & Linguado & 5 & 297.3 & $19.0-21.5$ & 16.7 & \\
\hline CARANGIDAE & & 1270 & 28637 & & & \\
\hline Chloroscombrus chrysurus & Palombeta & 744 & 13194.1 & $10.5-24.5$ & 33.3 & \\
\hline Oligoplites saliens & Guaivira & 1 & 43.3 & 20.5 & 8.3 & \\
\hline Parona signata & Pampo-do-alto & 1 & 156.5 & 26.0 & 8.3 & \\
\hline Selene setapinnis & Galo & 118 & 5306.5 & $8.5-22.0$ & 33.3 & \\
\hline Selene vomer & Galo-de-penacho & 3 & 54.1 & $4.0-15.5$ & 25.0 & \\
\hline Trachinotus carolinus & Pampo & 1 & 231.6 & $26.0-27.0$ & 8.3 & \\
\hline Trachurus lathami & Xixarro & 402 & 9650.8 & $4.5-17.0$ & 58.3 & \\
\hline CLUPEIDAE & & 285 & 5240 & & & \\
\hline Chirocentrodon bleekerianus & - & 67 & 340.6 & $5.0-12.0$ & 25.0 & \\
\hline Harengula clupeola & Sardinha-cascuda & 72 & 2508.7 & $12.0-18.0$ & 58.3 & \\
\hline
\end{tabular}




\begin{tabular}{|c|c|c|c|c|c|c|}
\hline Pellona harroweri & Sardinha-mole & 141 & 2239.5 & $9.0-14.0$ & 41.7 & \\
\hline Sardinella brasiliensis & $\begin{array}{l}\text { Sardinha- } \\
\text { verdadeira }\end{array}$ & 5 & 151.4 & $15.0-20.0$ & 16.7 & \\
\hline CONGRIDAE & & 14 & 2449 & & & \\
\hline Ariosoma opisthophtalma & - & 10 & 59.1 & $8.5-27.0$ & 8.3 & \\
\hline Conger orbignyanus & Congro & 4 & 2390.2 & $59.5-90.0$ & 33.3 & 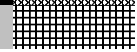 \\
\hline CYNOGLOSSIDAE & & 98 & 3203 & & & \\
\hline Symphurus plagusia & Língua-de-mulata & 68 & 1847.4 & $8.0-11.0$ & 75.0 & \\
\hline Symphurus diomedianus & Língua-de-mulata & 5 & 209.0 & $18.0-21.0$ & 8.3 & \\
\hline Symphurus jenynsi & Língua-de-mulata & 25 & 1146.5 & $14.5-17.0$ & 50.0 & \\
\hline DACTYLOPTERIDAE & & 493 & 25411 & & & \\
\hline Dactylopterus volitans & Falso-voador & 493 & 25411 & $7.0-35.5$ & 83.3 & \\
\hline DIODONTIDAE & & 112 & 7555 & & & \\
\hline Ciclichthys spinosus & Baiacu-de-espinho & 112 & 7554.5 & $6.0-19.5$ & 91.7 & 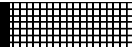 \\
\hline ENGRAULIDIDAE & & 4 & 123 & & & \\
\hline Anchoa marinii & Manjuba & 2 & 30.4 & $10.5-15.5$ & 16.7 & \\
\hline Lycengraulis grossidens & Manjubão & 2 & 92.6 & $16.5-20.0$ & 8.3 & \\
\hline EPHIPPIDAE & & 1 & 415.2 & & & \\
\hline Chaetodipterus faber & Paru & 1 & 415.2 & $21.0-41.0$ & 8.3 & \\
\hline FISTULARIIDAE & & 22 & 691.6 & & & \\
\hline Fistularia petimba & Peixe-trombeta & 22 & 691.6 & $42.0-70.0$ & 50.0 & \\
\hline GADIDAE & & 19 & 3544 & & & \\
\hline Urophycis brasiliensis & Abrótea & 19 & 3544.4 & $5.0-42.0$ & 33.3 & \\
\hline GEMPYLIDAE & & 6 & 215.5 & & & \\
\hline Thyrsitops lepidopoides & Cavalinha & 6 & 215.5 & $14.0-26.5$ & 16.7 & \\
\hline GERREIDAE & & 567 & 25851 & & & \\
\hline Eucinostomus argenteus & Carapicu & 513 & 23535.6 & $8.0-20.0$ & 66.7 & \\
\hline Eucinostomus gula & Carapicu & 54 & 2315.8 & $11.0-18.5$ & 33.3 & \\
\hline HAEMULIDAE & & 1028 & 67515 & & & \\
\hline Boridia grossidens & Cocoroca-sargo & 1 & 11.5 & 14.0 & 8.3 & \\
\hline Conodon nobilis & Roncador & 10 & 1346.3 & $18.0-32.0$ & 16.7 & \\
\hline Haemulon aurolineatum & Cocoroca & 7 & 361.2 & $14.0-20.5$ & 33.3 & \\
\hline Orthopristis ruber & Cocoroca & 1008 & 63890.4 & $7.5-28.0$ & 91.7 & \\
\hline Pomadasys corvinaeformis & Cocoroca & 2 & 1905.3 & $12.5-14.0$ & 8.3 & \\
\hline LOPHIIDAE & & 12 & 10399 & & & \\
\hline Lophius gastrophysus & Peixe-sapo & 12 & 10398.7 & $7.0-63.0$ & 25.0 & \\
\hline MERLUCCIIDAE & & 1 & 28 & & & \\
\hline Merluccius hubbsi & Merluza & 1 & 28 & 17.5 & 8.3 & \\
\hline MONACANTHIDAE & & 77 & 4360 & & & \\
\hline Stephanolepis hispidus & Peixe-porco & 77 & 4360.2 & $4.8-23.5$ & 75.0 & \\
\hline MULLIDAE & & 240 & 4220 & & & \\
\hline Mullus argentinae & Trilha & 1 & 60.2 & $13.5-20.5$ & 8.3 & \\
\hline Pseudupeneus maculatus & Salmonete & 1 & 72.4 & 17.5 & 8.3 & \\
\hline Upeneus parvus & Trilha & 238 & 4087 & $5-17.5$ & 75.0 & \\
\hline MURAENIDAE & & 1 & 128.8 & & & \\
\hline Gymnothorax ocellatus & Moréia-pintada & 1 & 128.8 & $43.5-44$ & 8.3 & \\
\hline OGCOCEPHALIDAE & & 222 & 1158 & & & \\
\hline Ogcocephalus notatus & Peixe-morcego & 1 & 4.7 & 6.0 & 8.3 & \\
\hline Ogcocephalus vespertilio & Peixe-morcego & 221 & 1152.9 & $4.0-14.5$ & 83.3 & \\
\hline
\end{tabular}


Cont. Table 2

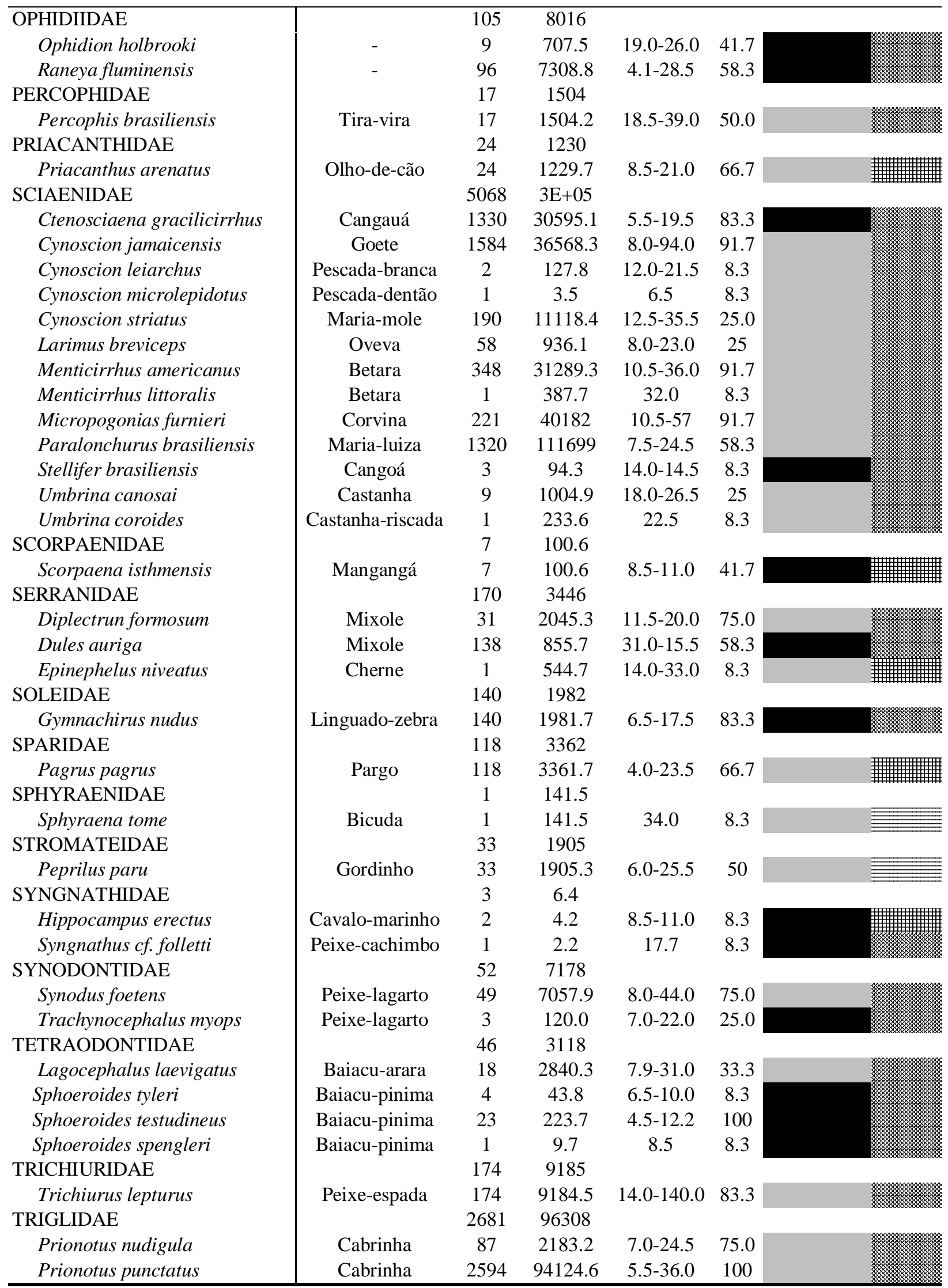


Table 3 - Percentage of captures in number of individuals and in weight, by family for bony fish, in the region sampled, during the study.

\begin{tabular}{lcc}
\hline & number & weight $(\mathbf{k g})$ \\
\hline Batrachoididae & 16.0 & 13.0 \\
Bothidae & 7.0 & 3.0 \\
Carangidae & 7.0 & 4.0 \\
Haemulidae & 6.0 & 9.0 \\
Sciaenidae & 30.0 & 37.0 \\
Triglidae & 16.0 & 13.0 \\
Others & 18.0 & 21.0 \\
\hline
\end{tabular}

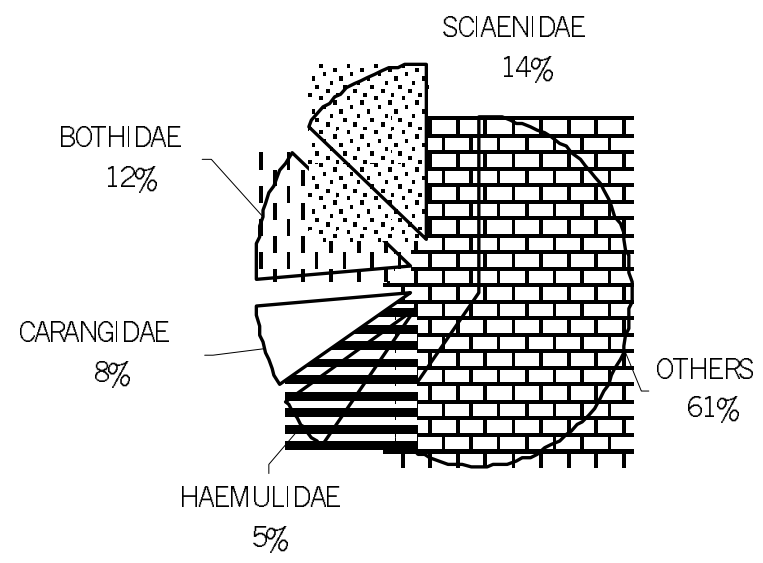

Figure 1 - Percentage of the number of species of bony fish registered by family, during the study.

Table 4 - Values of abundance of capture, index of biological diversity and relation in weight between Pink shrimp and species of fish analyzed, during the study.

\begin{tabular}{lcccccc}
\hline & Sep-Oct & Nov-Dec & Jan-Feb & Mar-Apr & May-Jun & Jul-Aug \\
\hline CPUEn (n.) & 399.2 & 414.2 & 131.2 & 127.2 & 757.1 & 257.7 \\
CPUEw (weight) & 15088.9 & 18129.8 & 5969.7 & 3032.3 & 30326.4 & 13408.4 \\
n. of species & 51 & 48 & 43 & 31 & 62 & 50 \\
Richness (n.) & 19.22 & 17.96 & 19.83 & 14.26 & 21.19 & 20.32 \\
Richness (weight) & 11.97 & 11.04 & 11.12 & 8.62 & 13.61 & 11.87 \\
Diversity (n.) & 1.10 & 0.95 & 1.11 & 1.00 & 1.26 & 1.25 \\
Diversity (weight) & 1.19 & 1.10 & 1.08 & 1.01 & 1.23 & 1.10 \\
Equitability (n.) & 0.65 & 0.56 & 0.68 & 0.67 & 0.70 & 0.73 \\
Equitability (weight) & 0.70 & 0.65 & 0.66 & 0.67 & 0.69 & 0.65 \\
Shrimp:bony fish (kg) & $1.0: 9.4$ & $1.0: 12.1$ & $1.0: 5.5$ & $1.0: 10.0$ & $1.0: 18.9$ & $1.0: 7.1$ \\
\hline
\end{tabular}

Of the bony fishes captured $49.5 \%$ of species were totally discarded by the fleet studied, regardless of quantity or size. The others were of some use, being commercialized either as mixture or separately. However, the use to which these species were put depended on the criteria normally adopted for on-board selection, with the result that the rejection rate rose and only larger individuals 
were, in fact sold. The species utilized were mostly sold in the mixture category. Exceptionally, when the quantity and size of individuals were very big, they were traded separately, but did not obtain good prices.

As regards the species highlighted, considering $\mathrm{L}_{50}$ (length of first gonadal maturation) as the dividing line between the young and adults it was observed that the percentage of captured individuals before maturity for Micropogonias furnieri $\left(\mathrm{L}_{50}\right.$ (female) $=27.5 \mathrm{~cm}$; Vazzoler, 1991) was of $67 \%$, of Menticirrhus americanus $\left(\mathrm{L}_{50}=18.0 \mathrm{~cm}\right.$; AlvitresCastillo, 1986) about 25\%, of Prionotus punctatus $\left(\mathrm{L}_{50}=5.2 \mathrm{~cm}\right.$; Peres-Rios, 1995) about $65 \%$ and of Orthopristis ruber $\left(\mathrm{L}_{50}\right.$ (female) $=15.3 \mathrm{~cm}$; Vianna and Verani, 2002) about 55\%.

\section{Distribution of species}

With the process of amalgamation the number of species studied was reduced to 37. Analyzing the group of discarded species, it was seen that they corresponded to those of low occurrence and capture frequency or those that hade pelagic behavior or were associated with the kind of environment in which deep trawling did not collect adequately. Once the 37 species were selected, Correspondence Analysis was employed and two dimensions were obtained with significant eigenvalues, which accounted for $89.9 \%$ of the inertial percentage, which was considered an excellent result in terms of the utilization of this technique (Fig. 2).

The Correspondence Analysis separated the fish assemblage into three clusters; one with high richness composed of species in which distribution was related to Coastal Water, more abundant from May to August and during collections in March and April (e.g. O. ruber, Pa. brasiliensis, M. americanus); another consisted of species with more restricted distribution associated with the cold water mass, with greater capture in November and February (e.g. P. porosissimus, $P$. patagonicus, L. gastrophisus); and a third cluster contained the species of more homogeneous distribution with high capture rates in SeptemberNovember, but also with good captures in the winter period due to the peak of fishing recruitment (e.g. C. gracilicirrhus, E. gula, E. crossotus).

\section{DISCUSSION}

The composition of the bycatch is specific for each kind of fishing and trawling for shrimp is undoubtedly the most damaging. Of the bony fishes registered during the study, the majority was demersal, common in areas like the study herein. The predominance of Sciaenidae in number of species as well as in weight corroborated Vazzoler et al. (1999) statements, which attributed importance to this family, for other geographical regions with similar beds. It also corresponded to what was found in the literature as to the composition of the bycatch in Brazilian shrimp fishing for the south (Ruffino and Castello, 1992/93), southeastern (Coelho et al., 1986) and north regions (Damasceno and Evangelista, apud. Isaac, 1999). This, thus, confirmed the dominance of this family in tropical estuary regions and warmer temperate regions, having been observed by Rocha and Rossi-Wongtschowski (1998) for the area sampled here.

The large number of species registered with, however, the numerical predominance of very few of them, was characteristic of the shrimp trawl bycatch in tropical waters (Clucas, 1998). In all works on fish captured together with shrimp in Brazil, in spite of there being a high number of species, few of them were responsible for the larger values of biomass and number of individuals. This situation was common in communities of tropical fish and agreed with what was found by Rossi-Wongtschowski and Paes (1993). However, the number of species registered was high even when compared to previous studies of the fishing bycatches of other species of shrimp in Brazil, as by Coelho et al. (1986), Haimovici and Mendonça (1996), Kotas (1998) and Damasceno and Evangelista (apud. Isaac, 1999). 


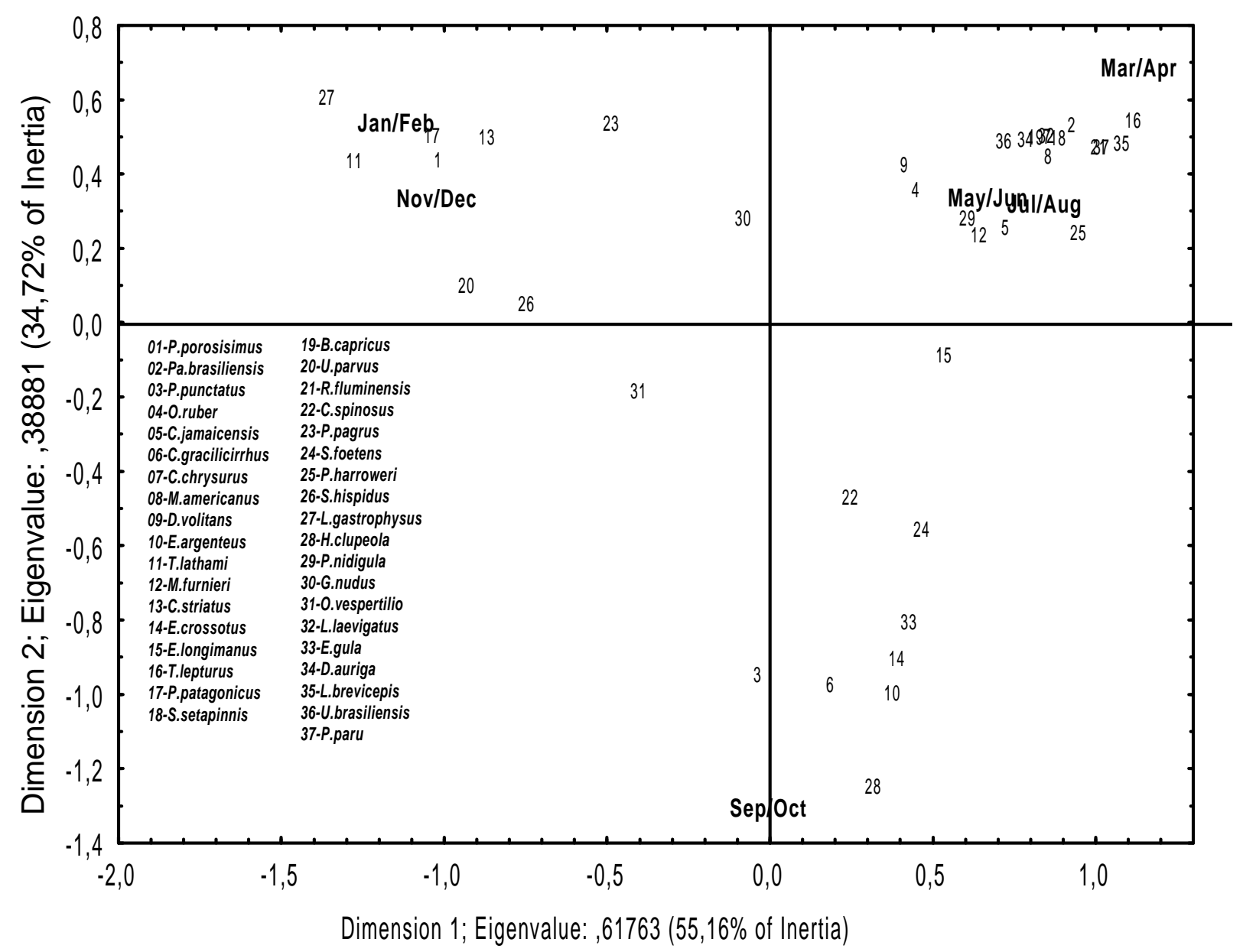

Figure 2 - Correspondence Analysis between species and bimonthly periods during the study.

Due to high biodiversity, currently one of the great concerns related to bycatches in the Tropics is the loss of genetic heritage. Thus, measures to limit exploitation must be applied during periods when larger captures affect fish assemblages with great species diversity. In the region studied, the beginning of winter seemed to be the most critical period, probably due to the occurrence of recruitment fishing peaks of some species, as registered to Orthopristis ruber (Vianna and Verani, 2002), and the presence of more coastal fish assemblages at various depth. In spite of the majority of component species presenting a broad geographical distribution, it was noticed that the large catch of Porichthys porosissimus, was a species restricted to southeastern/ southern South America, an area intensively exploited by trawl fishing (Vianna et al., 2000).
In the analyzed catches, Pink shrimp showed variation in CPUE greatly inferior to that of the bycatch, showing the leading in capture and making random the inclusion of registered fishes. Clucas (1998) found, that in tropical waters, shrimps generally were bigger than in temperate regions and coexisted with other animals of similar size or smaller, making these captures unavoidable. In Brazil Paiva-Filho and Schmiegelow (1986) quantified the bycatch for $X$. kroyeri in the southeastern and obtained a proportion of 1.0:1.08 between shrimps and fish. Ruffino and Castello (1992/93) analyzing the fishing of $A$. longinaris in the south, found relations of 1.0:12.7. Haimovici and Mendonça (1996) found an discard of 1.0:3.33 in fishing directed at $A$. longinaris and $P$. muelleri in the south. Kotas (1998) obtained data from shrimp fishing for P. muelleri, Plesionika longirostris, 
Metanephrops rubellus and Farfantepenaeus spp. and considered the Pink shrimp fisheries the most harmful, obtaining average values of as high as 1.0:13.0. Isaac (1999) working on $F$. subtilis estimated proportions of 1.0:5.0 in the north. In the present work, which considered only bony fishes, very high values for bycatch captures were registered and these numbers increase greatly when added to the weight of other species (e.g. rays) and reached higher values than those obtained in other studies. It was noticed that the relationship Pink shrimp:bycatch varied over the year and probably also changed with depth, which reflected in the composition as well as on individual sizes. The values obtained in this study represented a partial estimate, since one trawl per month was considered, and there could be great variation between hauls. However, this served as an indication of seasonal behavior for fishing in the range of the depths sampled.

Total rejection of much of the bony fish registered was due to the fact that they did not present a perciform format, which facilitated the acceptance of the product on markets. On the other hand, the discarding occured in part, due to the reduced size of great part of the individuals captured, similar to what was found by Isaac (1999) with F. subtilis, making their commercialization difficult. The high number of species of bony fishes totally rejected agreed with what was stated in Brazilian literature with regard to shrimp fishing (e.g. Haimovici and Mendonça, 1996) and even when considered the utilizable species, rejection remained very high (Kotas, 1998; Isaac, 1999). Although mostly the small fish are rejected, they tend greatly to deviate the production value weight of the total catch obtained from the unshipping. We considered that in this fishery each boat made approximately three voyages a month, each lasting around eight days, executing an average of four double trawls per night and all that in one small town alone. If we considered that during the sampling period not less than 26 boats were trawling for Pink shrimp, we would see that the area sampled suffered a high level of exploitation, and it must affected even those species which were least captured.

According to Clucas (1988), the presence of innumerable species of small length and no economic importance was typical of shrimp fishing bycatches in the tropics, Hall (1999) found that the problem in these regions did not harm future commercial captures but was more of an ecological question. Brazilian coast was not considered as one of high rejection, as compared with other areas. However, there are reports with a high level of rejection, including species which could be utilized as human food (Kotas, 1998; Isaac, 1999) and many of which are rejected before their first gonadal maturation, which constitutes overfishing (e.g. Vianna and Verani, 2002). In Brazil, although the fishery is less intense than in other countries, they are largely directed to capture of shrimp, thus resulting in a high discard rate of bottom bony fishes, mainly Sciaenidae.

In the management of fishing resources, it is, important to describe distribution patterns of fish assemblages related to environmental variation. The decline of commercially exploited populations can have an indirect influence, caused by alterations in the structural interrelationships of the community. Tropical fish assemblages such as those cited in this study, are predominantly shortlived species that responds quickly to fishery pressure; however, the complexity of these assemblages leads to highly sensitive interrelationships with slow recovery capacity.

On the southeastern Brazilian coast, due to the inflowing and outflowing of the water masses, the composition and abundance of species show oscillations, leading to modifications of distribution both as regards to temperature and depth. This seasonal pattern in the distribution and abundance of fish, corroborated by this study, confirmed that the region contained tropical and sub-tropical species with a preference for particular water masses, especially all in the depth zone sampled. The area studied corresponded to the mixing zone of the water masses and was a sub-system of variable contour. According to Rossi-Wongtschowski and Paes (1993) and Rocha and Rossi-Wongtschowski (1998), it was a place of small ichthyologic resilience with great species richness as a transition zone with overlapping of fish assemblages moving to their original regions along with the water masses. This area was the most exploited by trawl fisheries since it was precisely where occurred the overlapping of the fishing grounds of the fleets aiming for distinct shrimps. These oscillations in composition were reflected in the commercial captures and bycatches.

One of the main problems in the fishery management of the bycatch is that this resource is not regulated by economic value since it is not the purpose of the fishery. Hall (1999) observed that 
each fishery must be examined separately as regards its bycatch and that mitigation strategies must include selective breeding methods, and the closing of areas and seasons. López (1999) recommended regulations to avoid the capture of juvenile and the enhancement of marketing strategies and credits to incentive the lucrative exploitation of the bycatch. The use of BRD significantly reduced the shrimp bycatch in Australia and temperate regions (Clucas, 1998) and BRD models must be developed specifically for the Pink shrimp fishery in order to reduce the capture of juveniles without a great loss in the production of shrimp and other commercially important fishes. According to Alverson et al. (1994) the increase in operational costs, together with the fall in shrimp productivity were leading to the better use of trawls and consequently to less on-board rejection. Morais et al. (1995) described this behavior for Brazil pointing to the increase in the participation of fishes in the Sea-bob and Pink Shrimp catches. But in spite of the tendency to profit from fishes that previously were discarded, this still only happened to a few species and to large fishes, since the difference in their commercial value was huge, being as much as 1.0:15.0 (Isaac, 1999). Clucas (1998) suggested that the benefit of these products was in their added value and in the mitigation of the problem. Asiatic experiences in preparing products of high economic value, but also emphasizes the procedure adopted in Africa i.e., the making of cheap products for human consume or animal.

López (1999) suggested that even with the use of adequate BRD the bycatch was not totally avoided and its use, need to be encouraged. The question was also economics and culture. In Caribbean regions the discard rate reached $80 \%$ while in Cuba the bycatch utilization attained almost $100 \%$ (López, 1999). In Brazil, the feasibility of the economic use of rejected fish is a technological problem; according to Morais et al. (1995), the lack of processes for transforming bycatch into acceptable products, the difficulty in on-board handling and low financial return, discourage its use. Urgent measures must be taken in order to stimulate this exploitation, either through profiting from species discarded for cultural reasons, or by the use of small sized individuals, as raw material for value added or component products, or simply as protein supplements. It should also be considered that Brazilian fisheries have modern but idle installations due to the irregularity of the supply of raw material, which could be compensated by the utilization of unprofitable fishes, such as constitute the shrimp fishery bycatch (Morais et al., 1995).

The closed season measures for the Pink shrimp are regulated by the government and are in force from March to May, aiming only at the maintenance of shrimp stock, and the protection of its recruitment, but ignoring the bycatch. However, the same report concludes that stock administration for Pink shrimp depends more on the preservation of the juvenile stratum in breeding than in adult capture for the open sea. The existing closed season occurs at a less effective time for preservation of the bycatch bony fish of the Pink shrimp, because the closed season is after the reproduction main period (Vazzoler et al., 1999; Vianna and Verani, 2002) and before the season of greater recruitment (Vianna and Verani, op cit.). Adequacy of the closed shrimp season with opportune moments for to bycatch (reproduction peaks and recruitment), should be taken in order to reduce capture in critical moments. We suggest that the closed season should also cover the month of June, thus protecting recruitment of fish and reducing fishing in on the period of greatest diversity.

This study showed the critical situation on the exploitation of fishery resources on the Brazilian coast. The results demonstrated the contrast between the lack of protein for human food and the wastage at sea. The fishery community, responsible for the discarding of the bycatch, survives by exploiting this resource and is aware that it is finite and badly exploited. Only joint actions, including co-management among government, the production sector and research institutes will be capable of finding ways to solve this problem.

\section{ACKNOWLEDGEMENTS}

The authors would like to thank N. A. Menezes and J. L. Figueiredo for the identification of some species; J. P. Castello, M. Haimovici, A. A. R. Tomás, J. A. A. Perez, K. A. Keunecke and S. N. P. Lima for suggestions on the manuscript; and CNPq for the M.Vianna scholarship. 


\section{RESUMO}

A pesca de arrasto direcionada ao camarão-rosa, captura grande quantidade de peixes, em sua maioria teleósteos, que são rejeitados por não possuírem valor comercial. A composição e abundância destes foram estudadas em uma área no litoral sudeste do Brasil. Registramos 91 espécies e observou-se que a pesca incidental age principalmente sobre indivíduos jovens e ocorre durante o ano todo, produzindo um relação entre teleóteos e camarão de 10,5:1,0. Foram identificadas três ictiocenoses influenciadas pela sazonalidade das massas d'água, ocorrendo uma predominante associada a Água Costeira, outra associada a penetração da ACAS na plataforma e uma terceira com distribuição mais homogênea. $\mathrm{O}$ período mais crítico, para a captura da ictiofauna acompanhante, é o inicio do inverno devido a sobreposição de ictiocenoses e pico de recrutamento pesqueiro.

\section{REFERENCES}

Alverson, D. L.; Freeberg, M. H.; Pope, J. G. and Murawski, S. A. (1994), A global assessment of fisheries bycatch and discards. FAO Fish. Tech. Pap., 339, 233.

Alvitres Castillo, V. R. (1986), Estudo sobre a biologia e ciclo de vida de Menticirrhus americanus (Linnaeus, 1758) (Ubatuba 2330'S - Cananéia 25 05'S, São Paulo). M.Sc. Thesis, IO/USP, São Paulo.

CEPSUL (1994), Relatório da reunião técnica sobre camarões das regiões sudeste e sul do Brasil. Itajaí, IBAMA/MMA, 20.

Castro Filho, B. M.; Miranda, L. B. and Miyao, S. Y. (1987), Condições hidrográficas na plataforma continental ao largo de Ubatuba: variações sazonais e em média escala. Bolm. Inst. Oceanogr, 35 : (2), 135-151.

ClucaS, I. (1998), Bycatch - is it a bonus from the sea? Infofish Internacional, 3, 24-28.

Coelho, J. A. P.; Puzzi, A.; Graça-Lopes, R.; Rodrigues, E. S. and Prieto Jr., O. (1986), Análise da rejeição de peixes na pesca artesanal dirigida ao camarão Setebarbas (Xiphopenaeus kroyeri) no litoral do estado de São Paulo. B. Inst. Pesca, 13 : (2), 51-61.

Furtado, V. V. and Mahiques, M. M. (1990), Distribuição de sedimentos em regiões costeiras e plataforma continental norte do estado de São Paulo. In: Simpósio de Ecossistemas da costa sul e sudeste brasileira: Estrutura, função e manejo, 2., Águas de Lindóia. Anais... Águas de Lindóia, São Paulo. v.1. pp. 20-29.
Hall, S. J. (1999), The effects of fishing on marine ecosystems and communities. Fish Biology and aquatic resources series 1. Blackwell Science, 274.

Haimovici, M. and Mendonça, J. T. (1996), Descartes da fauna acompanhante na pesca de arrasto de tangones dirigida a linguados e camarões na plataforma continental do sul do Brasil. Atlântica, 18, 161-177.

Isaac, V. J. (1999), Fisheries bycatch in the northern coast of Brazil. In: Clucas, I. D. and Teutscher, F. (Eds.). Report and proceedings of FAO/DFID expert consultation on bycatch utilization in tropical fisheries. Beijing, 1998. pp. 273-294.

Kotas, J. E. (1998), Fauna acompanhante nas pescarias de camarão em Santa Catarina. Coleção Meio Ambiente. Série estudos pesca, 24, 76.

López, J. (1999), Bycatch utilization in the americas: an overview. In: Clucas, I. D. and Teutscher, F. (Eds.). Report and proceedings of FAO/DFID expert consultation on bycatch utilization in tropical fisheries. Beijing, 1998. pp. 53-83.

Ludwig, J. A. and Reynolds, J. F. (1988), Statistical ecology: A primer on methods and computing. A Wiley-Intersciense Publication. EUA.

Morais, C.; Valentini, H.; Almeida, L. A. S. and Coelho, J. A. P. (1995), Considerações sobre a pesca e aproveitamento industrial da ictiofauna acompanhante da captura do camarão-sete-barbas, na costa sudeste do Brasil. B. Inst. Pesca, 22 : (1), 103-114.

Paiva-Filho, A. M. and Schmiegelow, J. M. M. (1986), Estudos sobre a ictiofauna acompanhante da pesca do camarão Sete-Barbas (Xiphopenaeus kroyeri) nas proximidades da Baía de Santos-SP, I- Aspectos quantitativos. Bolm. Inst. Oceanogr., 34, 79-85.

Peres Rios, E. (1995), Aspectos reprodutivos de Prionotus punctatus (Bloch, 1797) (Teleostei: Triglidae) na região costeira de Ubatuba, São Paulo, Brasil. M.Sc Thesis, IO/USP, São Paulo.

Rocha, G. R. A. and Rossi-Wongtschowski, C. L. D. B. (1998), Demersal fish community on the inner shelf of Ubatuba, southeastern Brazil. Rev. Bras. Oceanogr., 46 : (2), 93-109.

Rossi-Wongtschowski, C. L. D. B. and Paes, E. T. (1993), Padrões espaciais e temporais da comunidade de peixes demersais do litoral norte do Estado de São Paulo-Ubatuba, Brasil. Publção. Esp. Inst. Oceanogr., 10, 169-188.

Ruffino, M. L. and Castello, J. P. (1992;93), Alterações na ictiofauna acompanhante da pesca do Camarãobarba-ruça (Artemesia longinaris) nas imediações da barra de Rio Grande, Rio Grande do Sul - Brasil. Nerítica, 7 : (1-2), 43 -55.

Sneath, P. H. A. and Sokal, R. R. (1973), Numerical taxonomy. San Francisco : W. H. Freeman and Co.

Vazzoler, A. E. A. M. (1962), Sobre a primeira maturação sexual e destruição de peixes imaturos. Bolm. Inst. Oceanogr, 12 : (2), 5-38. 
Vazzoler, A. E. A. M. (1991). Síntese dos conhecimentos sobre a biologia da corvina, Micropogonias furnieri (Desmarest, 1832) na costa do Brasil. Atlântica, 13 : (1), 55-74.

Vazzoler, A. E. A. M.; Soares, L. S. H. and Cunningham, P. T. M. (1999), Ictiofauna da costa brasileira. In: Estudos ecológicos de comunidades de peixes tropicais. EDUSP. pp. 424-521.

Vianna, M., Tomas, A. R. G. and Verani, J. R. (2000). Aspects of the biology of the atlantic midshipman, Porichthys porosissimus (Teleostei. Batrachoididae): an important by-catch species from the shrimp trawling off southern Brazil. Rev. Brasil. Oceanogr., 48 : (2), 133-142.

Vianna, M. and Verani, J. R. (2002). Biologia populacional de Orthopristis ruber, (Teleostei. Batrachoididae) espécie acompanhante da pesca do camarão-rosa no sudeste brasileiro. Atlântica, 24 : (1), 12-26. 